Journal

of Geography,

Politics and Society

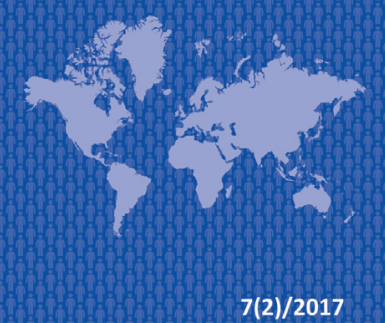

Journal of Geography, Politics and Society

$2017,7(2), 43-47$

DOI 10.4467/24512249JG.17.014.6630

\title{
THE FUNCTIONING OF THE POLISH-UKRAINIAN BORDER WITHIN CONDITIONS OF EUROPEAN INTEGRATION PROCESS INTENSIFICATION (ON THE EXAMPLE OF EUROREGION “BUH”)
}

\author{
Natalia Kotsan (1), Halyna Kopachynska (2) \\ (1) Country-Studies and Foreign Relations Department, Lesya Ukrainka Eastern European National University, Vynnuchenka 28, 43000 Lutsk, Ukraine, \\ e-mail: intrel-region.dep@eenu.edu.ua (corresponding author) \\ (2) Country-Studies and Foreign Relations Department, Lesya Ukrainka Eastern European National University, Vynnuchenka 28, 43000 Lutsk, Ukraine, \\ e-mail:kopachinskaja@gmail.com
}

\section{Citation}

Kotsan N., Kopachynska H., 2017, The Functioning of the Polish-Ukrainian Border within Conditions of European Integration Process Intensification (on the Example of Euroregion "Buh"), Journal of Geography, Politics and Society, 7(2), 43-47.

\begin{abstract}
The main functions of the state border, such as barrier, filter, contact are studied. It is proved that currently there is activation of contact function of the state border. It is underlined that the Ukrainian-Polish border is characterized by processes of contact function strengthening. Origins and political aspects of the formation and development of the Euroregion "Buh" in the Ukrainian-Polish border; the positive impact of cross-border cooperation within these structures on the socio-economic development of border areas; the prospects and ways of further intensification of Ukrainian-Polish border cooperation and positive effects from increased contact functions of the Ukrainian-Polish border are studied.
\end{abstract}

\section{Key words}

border, state, European integration, cross-border cooperation, the euro region, Ukraine, Poland.

\section{Introduction}

The state border executes main functions, such as barrier, contact, filter; and secondary functions, such as the separation, control, comparison. Depending on the geopolitical situation in international relations one of these functions is dominated or all of the functions are performed simultaneously. Through the implementation of the state border of the main and secondary functions interconnection the state economy with international economy is established.

In modern times intensification of the contact function of the state border is seen, what reflects objective processes of internationalization of economic reality, development of relations among states and development of interstate and crossborder cooperation. Cross-border cooperation is realized in various forms, new ones of them are clusters, triangles of growth, and traditional and nowadays the most effective euroregions are. At present times in the Ukrainian-Polish border there are two Euroregions, they are "Carpathian" and "Buh", what is a prime example of border contact function strengthening in terms of the intensification of the process of European integration. 
Ukrainian-Polish cross-border cooperation, its characteristics and trends (economic, humanitarian, environmental and other), legal support, history of development and formation of the Euroregion "Buh" is presented by sufficient quantity of publications, which include monographs, dissertation researches, scientific articles, etc. Among researchers of Ukrainian-Polish border cooperation including cross-border, such scientists as A. Bordun (Бордун, 2003), A. Vavrynyuk (Вавринюк, 2008), T. Komornicki, A. Miszczuk (2011), N. Kotsan (Коцан et al., 2008), A. Malinowska (Малиновська, 2002), A. Miszczuk (2013), A. Mrinska (Мрінська, 2005), J.M. Smutek, P. Łonyszyn (2016), G. Strilchuk (Стрільчук, 2005) and many others can be named. However, the impact of cross-border cooperation on the transformation of the functions of state borders and socioeconomic development of border areas are poorly studied areas.

The aim of the article is to identify the process of contact function strengthening of the UkrainianPolish border by Euroregion "Buh" creation. The goal was achieved by solving of such tasks as research of creation of euroregion in Ukrainian-Polish border; evaluation of its functioning and its impact on the social and economic development of border areas.

\section{Euroregion "Buh": new form of international cooperation}

Cross-border association Euroregion "Buh" was created on September 29, 1995 in Lutsk (Ukraine) (Стрільчук, 2005). The structure of the euroregion was formed by border areas of the two states - Poland and Ukraine. Treaty establishing the European region from Poland was signed by such provinces as: Chelm (Marian Tsihosh), Lublin (Edward Hunek) Tarnobrzeski (Paul Stavovy) Zamistskyy (Stanislav Rapa), and from the part of Ukraine the head of Volyn Regional State Administration B.P. Klimchuk signed the treaty.

On May 15, 1998 in the Belarusian city of Brest to the Euroregion "Buh" new members Podlasie and Brest regions were accepted. Two years later, on May 2000 to the Euroregion "Buh" Sokal and Zhovkva districtsof Lviv region were accepted.

By the end of 1998 ccross-border alliance included the border areas of the three states of Belarus, Poland and Ukraine and its territory was one of the largest of European euroregions. The total area of the euroregion amounted 82 thousand $\mathrm{km}^{2}$, of which the Polish part was $35.6 \%$, Belarussian was $39.9 \%$ and Ukrainian was 24.5\% (Перепелиця, 2009).
Due to administrative changes of 1998-1999 in euroregion former Tarnobrzeski province was excluded and thereby the total area of the euroregion decreased, which became about 64 thousand $\mathrm{km}^{2}$ with a population of 6.9 million people.

On June 3, 1996 Euroregion "Buh" became a member of the Association of European Border Regions, from 1998 has a representative in the administration of the mentioned above association. Another important institution that operates actively in terms of European integration, is established in 2001 and associated with CBC the European Centre of integration and cross-border partnership "House of Europe".

The main purpose of cross-border association of Euroregion "Buh" is the development of border areas and cooperation in the following areas: territorial planning; transport and communications; education, health, culture, sports and tourism; protection and enhancement of the environment; liquidation of emergencies and natural disasters; promoting contacts among inhabitants of border areas, cooperation among organizations and institutions and business entities.

The governing bodies of the Euroregion "Buh" are: Council of the European region; the Bureau of the European region; Euroregion Secretariat; Audit Commission.

To address common challenges in Euroregion "Buh" working groups were formed.

\section{Contact functions of Euroregion "Buh"}

During the existence of the Euroregion "Buh" in its territory a number of programs and projects with EU structures participation were implemented. Polish accession to the EU provided more opportunities to attract financial support from the European Commission. Borderland Volyn region participates in such programs and projects as INTERREG, PHARE $C B C$, TACIS CBC, which were implemented with the participation of the EU since the late $90 \mathrm{~s}$, what is one of the manifestations of contact function of Ukrainian-Polish border functioning in the intensification of the process of European integration (Мрінська, 2005).

One of the manifestation of the realization of contact function of Ukrainian-Polish border within the Euroregion "Buh" is intensification of cooperation in issues related to environmental protection in the border areas. An example of this is the implementation of the environmental program "Clean Buh", which aims to solve the current problems of the protection and restoration of the river, which flows through the territories of three neighboring 
states, which are Poland, Ukraine and Belarus. Also from 2002, a project "Joint River Basin Management. Basin Management of river Pripyat" is realized, its aim is to harmonize the coordinated management of international river basins (river Pripyat) through the introduction of European regulations. Within this project the training of specialists of analytical department of Ministry of Environmental Resources of several regions of Ukraine was carried out.

Another manifestation of the realization of border contact function within the researched euroregion is functioning of cross-border strategies and creation of project which aim is to prevent floods in the basin of Western Buh. The implementation of them started in the Volyn region from 2004, when a working group was founded, which included experts from border regions of Ukraine, Poland and Belarus.

Contact function of Ukrainian-Polish border within Euroregion "Buh" is realized also in economic cooperation. So, from July 2002 with the assistance of the Regulatory reform program in the region project "BIZPRO" is realized, the essence of which is to provide long-term support to small and medium enterprises in order to rise the economic development of Ukraine. The "BIZPRO" realizes number of programs to stimulate private enterprises. In Volyn region the program is implemented by Center of municipal reforms "Lutsk-1432" in three cities of regional importance (Lutsk, Kovel, Novovolynsk) and Gorokhiv district (Коцан et al., 2008).

From 2002 by the EU assistance Volyn region participates in the project "Establishment of network business internet centers in Ukraine cities, where insufficiently developed telecommunications are" in order to promote economic growth and providing regions of Ukraine with underdeveloped telecommunications and business infrastructure services for business development and access to modern information and communication technologies The project aims to develop in the small towns of Ukraine services of business consulting for implementation business specialized - training programs, implementation of marketing strategies for small and medium businesses, the use of information technologies.

Appropriation of 2.75 million euros for the reconstruction and expansion of international road exit of checkpoint "Yagodyn-Dorohusk" is planed by the project "Improving of border management" which is implemented in the region from 2003 (Бордун, 2003). European Commission held a tender to determine the regulatory authority for the practical implementation of work provided by technical objectives of the project. In February 2004 its winner company "Louis Berger" (France) became (Вавринюк, 2008).
Another example of the implementation of the contact function of Ukrainian-Polish border in the economic sphere is the operation of the project "Improving the environment for small and medium enterprises development", implemented from 2003 in Volyn and Ivano-Frankivsk regions of Ukraine. Its purpose is to promote economic growth and poverty reduction through private sector development and the development of small and medium businesses. During the period of implementation of the project a number of international events were carried out.

From October 2004 until today within the framework of cross-border cooperation program of PHARE, which is spread on the territories of the members of the Euroregion "Buh", namely the border regions of Poland, Ukraine and Belarus, in the region the project "Development of institutional cooperation in promoting entrepreneurship in border regions of Poland, Ukraine and Belarus" is realized. The purpose of the project is strengthening the institutional cooperation in the sector of entrepreneurship and innovation in the aforementioned areas.

Also from January 2004 the project "UkrainianPolish cross-border agency - together in the future" continues to be implemented. The main objective of the project is to create a Ukrainian-Polish cross-border agencies on the basis of four regions of the two countries (Volyn and Lviv region of Ukraine, Lublin and Podkarpackie provinces of Poland), which aims to occupy a central place in the work on the Ukrainian-Polish border and to engage in their activities other existing structures, including the Euroregion "Buh". Other components of the project is to develop a common and shared cross-border regional development strategy and the creation of cross-border projects.

Manifestation of contact function of UkrainianPolish border within Euroregion "Buh" is also cooperation aimed at promoting local democracy. Thus, the program "Increasing opportunities to use European funds by the authorities of the border regions of Poland and Ukraine" was realized in the first half of 2004. In its framework training for representatives of local executive and self-governing bodies, as well as non-profit organizations was conducted on February 26-27, 2004.

On May 2003 in the frame of program "City of Lublin as a place of cooperation of local authorities of East and West" the representatives of the region took part in the Polish-Belarusian-Ukrainian roundtable dedicated to the activities of self-government, and also became participants of training in the organs of self-government communes and counties of Lublin province. On the results of the project 
implementation index of proposals on the questions of establishment of cross-border cooperation among the authorities and the local communities of the border regions of the three members of the Euroregion "Buh" was prepared and issued in printed version.

Another manifestation of the activation of contact function of Ukrainian-Polish border is the awakening of tourism activity within the Euroregion "Buh", implementation of which is influenced by small tourism projects with the financial support of PHARE. One of them is the project of 2003 "Implementation of training seminars on the questions of green tourism in Volyn region initiation". The project intends to disseminate information about rural tourism among residents of the region and reviewing desirous with the experience of this type of business in Poland (Стрільчук, 2005).

Thanks to the dissemination of information, organization of trainings and round tables interest of local people to this type of business has increased significantly. Already at the end of 2003 in several districts private, mostly family firms that provide complex of tourist services started their activity. Results of these small project were used for further expansion of cross-border tourism cooperation. In particular, based on it the joint project "Development of agro-tourism in the Euroregion "Buh", which was financially supported by the PHARE program and implemented by the Polish side, in partnership with the public association "Volyn perspectives" was prepared.

Also, in public association "Volyn prospects" the information center for support and development of green tourism in Volyn region functions. Today 22 ourist agricultural dwelling are well equipped.

For the development of cross-border cooperation in the tourism industry contributes the Ukrainian-Polish-Belarusian project "Track" EU triangle of friendship: Lublin-Lutsk-Brest", which is funded by PHARE program from the funds of small EU projects, implementation of which in Volyn region started from January 2004. Main objective of the project is the study of general concept of tourism development in the Euroregion "Buh" (Коцан et al., 2008).

In the process of another tourist project of PHARE program realization from the funds of small EU projects "Creation of office service of tourist traffic in cultural and entertainment center of the city Zvyezhynets" the ceremonial opening of the newly created point of tourist information in the city Zvyezhynets (Poland) happened, the concept of its arrangement by participation of Ukrainian and Polish specialists was worked out.
As the result of implementation of Ukrainian-Polish border contact function within the Euroregion "Buh" participating countries worked out a number of other interesting and promising ideas that can be used as a basis for the development of joint projects in such areas as environmental protection, tourism, software, local economic development, democracy and local government, as well as social and cultural spheres. Several small cross-border projects can be realized with the financial support of PHARE "The eastern border of Poland".

\section{Local programs and projects}

Intensification of international cooperation within the Euroregion "Buh" on the project level creates favorable conditions for the implementation of the new European Neighbourhood and Partnership Instrument (ENPI), which aim is to facilitate the development of an area of prosperity and good neighborliness between the EU and partner countries covered by the European Neighbourhood Policy (ENP).

The specific objectives and issues, which are developed in each program will be formed on local perspectives of ENPI CBC program partners reflecting local priorities. Management of programs will be the joint responsibility of local program partners.

Programs will be able to support a range of projects, from small local initiatives with local administrations and non-governmental civil society organizations to large-scale projects involving a large number of partners at the regional and sub-national levels. Program of trans border cooperation ENPI will also provide investments in cross-border context.

With the introduction of ENPI nature of the EU assistance was further reinforced by increasing resources, including total funding, which is available for Ukraine and will count 100.5 million euros (Перепелиця, 2009).

The purpose of border cooperation program "Poland-Belarus-Ukraine" is social and economic development of border areas and their integration. This program provides cooperation in several areas of priorities. They include: increasing the competitiveness of the border area; improving quality of life; development of cross-border cooperation and interpersonal contacts and networking initiatives by local communities.

Implementation of the ENPI through border cooperation program "Poland-Belarus-Ukraine" will promote: economic and social development in border areas; cooperation in addressing of common challenges in such fields as environment, health, the fight against organized crime; ensuring of efficient 
and secure borders; help in advancing human contacts in the Ukrainian-Polish border.

\section{Summary}

It is proved that territories that became parts of the Euroregion "Buh" share a common history. It was studied that during functioning of the Euroregion "Buh" a number of interesting and promising ideas that can be used as a basis for the development of joint projects in areas such as local development, democracy and local government as well as social, cultural and other fields were worked out.

Several small cross-border projects can be realized within the financial support of PHARE program "The eastern border of Poland". With the introduction of European Neighbourhood Policy by the EU, and through it - the European Neighbourhood and Partnership Instrument (ENPI) overall funding available for Ukraine was increased. Implementation of the program "Poland-Belarus-Ukraine" will promote economic and social development in border areas; cooperation in addressing of common challenges in fields such as environment, public health and the prevention and fight against organized crime; ensuring efficient and secure borders; help to advance human contacts in the Ukrainian-Polish border.

All these processes are manifestation of contact functions of Ukrainian-Polish border strengthening that in future will have a positive impact on the deepening of the integration process between Ukraine and Poland in particular, and the whole European Union.

\section{References}

Komornicki T., Miszczuk A., 2011, Transgraniczne powiqzania województw Polski wschodniej, Ekspertyza wykonana na potrzeby nowej strategii rozwoju Polski Wschodniej, Ministerstwo Rozwoju Regionalnego, Warszawa.

Miszczuk A., 2013, Uwarunkowania peryferyjności regionu przygranicznego, Norbertinum, Lublin.

Smutek J.M., Łonyszyn P., 2016, Cross-border issues in Polish supraregional strategies on example of strategies of western and eastern Poland, Journal of Geography, Politics and Society, 6(2), 32-44.

Бордун О.Ю., 2003, Транспортна інфраструктура західноукраїнського прикордоння: економіко-географічне дослідження, PhD typescript: ЛНУ ім. І. Франка, Львів.

Вавринюк А.А., 2008, Сучасна діяльність польської частини єврорегіону "Буг" (суспільно-географічний аналіз), РВВ “Вежа" Волин. нац. ун-ту ім. Лесі Українки, Луцьк.

Коцан Н.Н., Вавринюк А.А., Коцан Р.І., 2008, Сучасні проблеми розвитку польсько-українського транскордонного співробітництва в єврорегіоні "Буг", Науковий вісник Волинського національного університету імені Лесі Українки. Географрічні науки, 1, 99-105.

Малиновська О.Ю., 2002, Політико-географічні аспекти формування та функціонування західного державного кордону України, PhD typescript: Київ. нац. ун-т ім. Т. Шевченка, Київ.

Мрінська О.В., 2005, Регіональна політика в країнах Європейського союзу і можливості використання ії досвіду в Україні (суспільно-географічне дослідження, $\mathrm{PhD}$ typescript: Київ. нац. ун-т ім. Т. Шевченка, Київ.

Перепелиця Г.М., 2009, Нові інструменти "східного партнерства" і можливості для України, [in:] Транскордонне співробітничтво на нових східних кордонах ЄС: Maтеріали круглого столу, Поліграфцентр “Ліра", Ужгород, 152-158.

Стрільчук Р.С., 2005, Хроніка найважливіших подій становлення українсько-польського транскордонного регіону, [in:] Європейські інтеграчійні процеси і транскордонне співробітничтво : міжнародні відносини, економіка, політика, географія, історія, право: Тези доn. II Міжнар. наук.-практ. конф. студ., асп. і молодих науковців, РВВ “Вежа" Волин. держ. ун-ту ім. Лесі Українки, Луцьк, 67-69. 